\title{
PENERAPAN KEDAULATAN RAKYAT DI DALAM PEMILIHAN UMUM DI INDONESIA BERDASARKAN UNDANG-UNDANG DASAR NEGARA REPUBLIK INDONESIA TAHUN 1945
}

\author{
Ofis Rikardo ${ }^{1}$
}

\begin{abstract}
Elections are a means of implementing the sovereignty of the people regulated in the 1945 Constitution. In the implementation of indirect democracy, a representative democratic system is inevitable, so that elections that uphold direct, public, free, secret, honest and fair spirit are a means of regenerating leadership politics to run the government both at central and regional levels. People as the owner of the highest sovereignty surrender their sovereignty to state institutions such as the President, DPR, DPD, and DPRD through elections. After the change in the 1945 Constitution there was a shift in the regulation of popular sovereignty such as the MPR is no longer the executor of popular sovereignty, the implementation of direct presidential elections by the people, until the emergence of the Constitutional Court that can try and decide the president and vice president to stop in his term of office. All of this is an effort to uphold the people's sovereignty and at the same time to maintain the people's sovereignty based on the 1945 Constitution.
\end{abstract}

Keywords: People's Sovereignty, Elections, 1945 Constitution

\begin{abstract}
ABSTRAK
Pemilu merupakan sarana pelaksanaan dari kedaulatan rakyat yang diatur dalam UUD Tahun 1945. Dalam penerapan demokrasi tidak langsung, sistem demokrasi perwakilan sebagai hal yang tidak dapat dielakkan, sehingga pemilu yang menjunjung tinggi semangat langsung, umum, bebas, rahasia, jujur dan adil merupakan sarana regenerasi kepemimpinan politik untuk menjalankan pemerintahan baik di tingkat pusat maupun daerah. Rakyat sebagai pemilik kedaulatan tertinggi menyerahkan kedaulatannya kepada lembaga negara seperti Presiden, DPR, DPD, dan DPRD melalui pemilu. Pasca perubahan UUD Tahun 1945 terjadi pergeseran dalam pengaturan kedaulatan rakyat seperti MPR tidak lagi sebagai pelaksana kedaulatan rakyat, pelaksanan pemilihan presiden langsung oleh rakyat, hingga munculnya Mahkamah Konstitusi yang dapat mengadili dan memutus presiden dan wakil presiden untuk berhenti dalam masa jabatannya. Semua ini merupakan upaya untuk menegakkan kedaulatan rakyat dan sekaligus untuk menjaga kedaulatan rakyat itu berdasarkan UUD Tahun 1945.
\end{abstract}

Kata kunci: Kedaulatan Rakyat, Pemilu, UUD Tahun 1945

${ }^{1}$ Dosen Tetap Fakultas Hukum Universitas Bhayangkara Jakarta Raya, Jalan Raya Perjuangan, Marga Mulya, Bekasi Utara - Kota Bekasi. Email : ofis.rikardo@dsn.ubharajaya.ac.id 


\section{PENDAHULUAN}

Bergulirnya reformasi tahun 1998 menandai berakhirnya kekuasaan otoritarianisme Orde Baru Soeharto yang telah berkuasa selama 32 tahun. Berakhirnya Orde Baru merupakan gerbang pembuka masuknya Indonesia pada fase reformasi di segala tatanan kehidupan berbangsa dan bernegera. Reformasi juga merambah pada perubahan sistem ketatanegaraan Indonesia melalui perubahan UUD Tahun 1945 hingga dilakukan sebanyak empat kali perubahan.

Perubahan UUD Tahun 1945 tidak dapat dielakkan, perjalanan bangsa Indonesia yang telah berumur lebih dari lima dekade, merupakan sebagai momentum untuk melakukan evaluasi dan perubahan terhadap konstitusi. Lahirnya UUD Tahun 1945 di saat waktu yang sempit menghasilkan sebuah konstitusi jauh dari lengkap dan sempurna. Bung Karno sangat memahami ihwal ini yang tercermin dari kata sambutannya sebagai Ketua PPKI pada tanggal 18 Agustus 1945 yaitu: “... Tuan-tuan semuanya tentu mengerti, bahwa UUD Tahun 1945 yang kita buat sekarang ini adalah UUD sementara. Kalau boleh saya memakai perkataan: ini adalah UUD kilat! Nanti kalau kita telah bernegara dalam suasana lebih tenteram, kita tentu akan mengumpulkan kembali MPR yang dapat membuat UUD lebih lengkap dan sempurna, UUD kilat, bahwa barangkali boleh dikatakan pula, inilah revolutie grondwet. Nanti kita membuat UUD yang lebih sempurna dan lengkap..."2.

UUD Tahun 1945 saat itu hanya dijadikan alat saja untuk sesegera mungkin membentuk negara merdeka yang bernama Republik Indonesia. UUD Tahun 1945 memang dirancang sebagai UUD yang sementara yang dalam istilah Bung Karno disebut 'revolutie grondwet' atau UUD kilat, apabila sudah memungkinkan harus diganti dengan UUD yang baru.

Ihwal ini dapat dilihat dari UUD Tahun 1945 tidak dijadikan refrensi dalam pengambilan keputusan kenegaraan dan pemerintahan. Alih-alih ingin menjadikan UUD Tahun 1945 sebagai landasan dalam berbangsa dan bernegara, pendiri bangsa di awal mula kelahiran UUD Tahun 1945 malah mengesampingkan UUD Tahun 1945 itu sendiri. Ni'matul Huda justru berpandangan peristiwa ketatanegaraan pemilihan presiden dan wakil presiden sebagai sebuah peristiwa yang tidak menjalankan pasal-pasal UUD Tahun $1945^{3}$. Contohnya ialah presiden dan wakil presiden yang seharusnya dipilih oleh MPR sebagaimana amanah dari Pasal 6 ayat (2) UUD Tahun 1945 ternyata dipilih oleh PPKI menurut Pasal III Aturan Peralihan. ${ }^{4}$ Penyusunan UUD Tahun 1945 sengaja memberikan Aturan Peralihan ini sebagai 'jalan pintas' atas kondisi saat itu yang belum memiliki MPR dalam menjalankan tugasnya untuk memilih presiden dan wakil presiden.

Sifat sementaranya UUD Tahun 1945 ini dapat dilacak pada Aturan Tambahan UUD Tahun 1945 yang berbunyi:. "Enam bulan sesudah berakhirnya

${ }^{2}$ Adnan Buyung Nasution, Arus Pemikiran Konstitusionalisme : Tata Negara (Jakarta : Kasta Hasta, 2007), hlm. 171

${ }^{3}$ Ni'matul Huda, Hukum Tata Negara Indonesia (edisi revisi), (Jakarta : 2014, Rajawali Pers) hlm. 118

${ }^{4}$ Republik Indonesia (1) Undang-Undang Dasar Negara Republik Indonesia (UUD NRI) Tahun 1945 (sebelum perubahan), Pasal III Aturan Peralihan

${ }^{5}$ Republik Indonesia (1), Ibid., Aturan Tambahan 
perang Asia Timur Raya, MPR harus dibentuk, dan enam bulan sesudah dibentuk MPR harus bersidang untuk menetapkan UUD baru”. Bunyi Aturan Tambahan ini menegaskan ada keharusan agar setelah berakhirnya perang Timur Asia Raya, MPR harus dibentuk dan enam bulan sesudah MPR dibentuk MPR harus bersidang untuk menetapkan undang-undang dasar baru. Ihwal ini kembali menegaskan pernyataan Bung Karno UUD Tahun 1945 adalah undang-undang dasar kilat yang bersifat sementara yang hanya dipersiapkan untuk selama enam bulan saja sejak perang Asia Timur Raya.

Apabila dilacak sejarah ketatanegaraan Indonesia, upaya membuat konstitusi baru telah dilakukan oleh Konstituante, 1956-1959. Namun upaya tersebut tidak berakhir dengan terbentuknya konstitusi baru karena saat deadlock dan di tengah reses Konstituante, pada 5 Juli 1959 Soekarno membubarkan Konstitante dan menandai pemberlakuan kembali UUD Tahun $1945 .^{6}$

Hingga kemudian setelah 54 tahun Indonesia merdeka yaitu setelah adanya desakan untuk mengubah UUD Tahun 1945 pada tahun 1999. Sehingga tidak berlebihan kemudian muncul sebuah kesimpulan masa pemerintahan Orde Lama dan Orde Baru ingin menggunakan UUD Tahun 1945 yang sementara itu untuk digunakan selama-lamanya. Di masa Orde Lama dan Orde Baru menganggap UUD Tahun 1945 sebagai benda 'kramat', yang tidak mungkin untuk diubah. Dengan segala kekurangannya, UUD Tahun 1945 tetap digunakan hingga terjadinya perubahan pertama yang dimulai pada tanggal 19 Oktober 1999

Keinginan menggunakan UUD Tahun 1945 secara terus menerus terlihat dari menjadikan 'kelemahan' UUD Tahun 1945 sebagai celah untuk mempertahankan kekuasaan bahkan cenderung menyalahgunakan kekuasaan itu. Bentuk menjadikan UUD Tahun 1945 untuk mempertahakan kekusaan ialah sangat terlihat pada pemerintahan Orde Baru dimana pemerintah mengartikan Pasal 7 UUD Tahun 1945 presiden dan wakil presiden memegang jabatannya selama lima tahun, dan sesudahnya dapat dipilih $\mathrm{kembali}^{7}$ sesuai dengan syahwat penguasa. Orde baru mengartikan jabatan presiden dan wakil presiden selama lima tahun dan dapat dipilih kembali tanpa ada batasan dipilih kembali untuk maksimum berapa lama pemilihan. Ihwal ini yang membuat kekuasaan Orde Baru dapat bertahan selama lebih dari enam periode pemilihan presiden hingga akhirnya terjadinya reformasi tahun 1998 .

Dengan adanya kelemahan yang terdapat dalam UUD Tahun 1945 ini, memberikan dorongan untuk melakukan perubahan terhadap UUD Tahun 1945. Materi perubahan tersebut tak pelak menyetuh pada pasal-pasal krusial yang menyangkut mengenai pasal-pasal ihwal kedaulatan rakyat:

Pasal 1 ayat (2) $:^{8}$

Kedaulatan berada di tangan rakyat dan dilaksanakan menurut Undang-Undang Dasar

\footnotetext{
${ }^{6}$ Saldi Isra (1), Pergeseran Fungsi Legislasi, (Depok : Rajawali Pers, 2018), hlm. 135

${ }^{7}$ Republik Indonesia (2), Undang-Undang Dasar Negara Republik Indonesia (UUD NRI) Tahun 1945 (setelah perubahan), Pasal 1 ayat (2)

${ }^{8}$ Republik Indonesia (2), Ibid., Pasal 1 ayat (2)
} 
Pasal 6A ayat (1) $:^{9}$

Presiden dan Wakil Presiden dipilih dalam satu pasangan secara langsung oleh rakyat

Pasal 6A ayat (2) $:^{10}$

Pasangan calon Presiden dan Wakil Presiden diusulkan oleh partai politik atau gabungan partai politik peserta pemilihan umum sebelum pelaksanaan pemilihan uтum

Pasal $7:{ }^{11}$

Presiden dan Wakil Presiden memegang jabatan selama lima tahun, dan sesudahnya dapat dipilih kembali dalam jabatan yang sama, hanya untuk satu kali masa jabatan

Pasal 7B: $:^{12}$

Usul pemberhentian Presiden dan/atau Wakil Presiden dapat diajukan oleh Dewan Perwakilan Rakyat kepada Majelis Permusyawaratan Rakyat hanya dengan terlebih dahulu mengajukan permintaan kepada Mahkamah Konstitusi untuk memeriksa, mengadili, dan memutus pendapat Dewan Perwakilan Rakyat bahwa Presiden dan/atau Wakil Presiden telah melakukan pelanggaran hukum berupa pengkhianatan terhadap negara, korupsi, penyuapan, tindak pidana berat lainnya, atau perbuatan tercela; dan/atau pendapat bahwa Presiden dan/atau Wakil Presiden tidak lagi memenuhi syarat sebagai Presiden dan/atau Wakil Presiden.

Pasal-pasal yang mengatur ihwal kedaulatan rakyat jauh berbeda dengan yang terdapat pada UUD Tahun 1945 sebelum perubahan :

Pasal 2 ayat $(1):{ }^{13}$

Kedaulatan adalah di tangan rakyat, dan dilakukan sepenuhnya oleh Majelis Permusyawaratan Rakyat.

Pasal 6 ayat (2) $:^{14}$

Presiden dan Wakil Presiden dipilih oleh Majelis Permusyawaratan Rakyat dengan suara yang terbanyak.

Pasal $7:^{15}$

Presiden dan Wakil Presiden memegang jabatannya selama masa lima tahun, dan sesudahnya dapat dipilih kembali.

\footnotetext{
${ }^{9}$ Republik Indonesia (2), Ibid., Pasal 6A ayat (1)

${ }^{10}$ Republik Indonesia (2), Ibid., Pasal 6A ayat (2)

${ }^{11}$ Republik Indonesia (2), Ibid., Pasal 7

${ }^{12}$ Republik Indonesia (2), Ibid., Pasal 7B

${ }^{13}$ Republik Indonesia (1), Op. Cit., Pasal 2 ayat (1)

${ }^{14}$ Republik Indonesia (1), Op. Cit., Pasal 6 ayat (2)

${ }^{15}$ Republik Indonesia (1), Op. Cit., Pasal 7
} 
Pasal $8:{ }^{16}$

Jika Presiden mangkat, berhenti, atau tidak dapat melakukan kewajibannya dalam masa jabatannya, ia diganti oleh Wakil Presiden sampai habis waktunya.

Pasal 19 ayat $(1):^{17}$

\section{Anggota Dewan Perwakilan Rakyat dipilih melalui pemilihan umum}

Berdasarkan uraian di atas, penting untuk dikaji bagaimana penerapan pelaksanaan kedaulatan rakyat dalam pemilihan umum (pemilu) di Indonesia berdasarkan UUD Tahun 1945, sehingga dapat diketahui bagaimana prinsip-prinsip kedaulatan rakyat yang diatur dalam UUD Tahun 1945 dapat diterapkan menuju Indonesia yang berkedaulatan rakyat.

\section{PEMBAHASAN}

\section{Pemilihan Umum Sebagai Sarana Pelaksanaan Kedaulatan Rakyat}

Dalam hubungan antara rakyat dengan kekuasaan negara dalam hubungan sehari-hari, ada dua teori yang lazim dikembangkan, yaitu teori demokrasi langsung (direct democracy) dan teori demokrasi tidak langsung (representative democracy). Artinya kedaulatan rakyat dapat dilakukan secara langsung dimana rakyatlah yang melaksanakan kekuasaan tertinggi yang dimilikinya. Namun, di zaman modern sekarang ini dengan kompleksitas permasalahan yang dihadapi, bentuk semacam ini hampir tidak lagi dapat dilakukan. Karena itu, hal yang lebih populer dewasa ini adalah ajaran demokrasi yang tidak langsung atau demokrasi perwakilan (representative democracy). ${ }^{18}$

Karena ihwal ini, negara-negara modern memiliki badan atau lembaga perwakilan rakyat yang bertindak sebagai pelaku atau pelaksana kedaulatan rakyat dalam kekuasaan negara sehari-hari. Pengisian jabatan keanggotaan badan atau lembaga perwakilan itu biasanya dilakukan melalui mekanisme pemilu yang menghimpun dan mengorganisasikan aspirasi, pendapat, dan suara rakyat yang berdaulat itu. Oleh karena itu, sistem demokrasi atau paham kedaulatan rakyat dewasa ini selalu terkait dengan pemilu dan partai politik. Dan bahkan terkadang melalui pelaksanaan pemilu dan keberadaan partai politik suatu negara dapat ditentukan pula negara tersebut sudah demokrasi atau tidak.

Penyaluran kedaulatan secara langsung (direct democracy) dilakukan melalui pemilu, pemilihan presiden, dan sebagai tambahan yaitu pelaksanaan referendum untuk menyatakan persetujuan atau penolakan terhadap rencana perubahan atas pasal-pasal tertentu dalam Undang-Undang Dasar. Bentuk penyaluran kedaulatan rakyat lainnya yaitu melalui pelaksanaan hak atas kebebasan berpendapat, hak atas kebebasan pers, hak atas kebebesan informasi, hak atas kebebasan berorganisasi dan berserikat serta hak-hak asasi lainnya yang dijamin dalam Undang-Undang

\footnotetext{
${ }^{16}$ Republik Indonesia (1), Op. Cit., Pasal 8

${ }^{17}$ Republik Indonesia (1), Op. Cit., Pasal 19 ayat (1)

18 Jimly Asshiddiqie (1), Gagasan Kedaulatan Rakyat Dalam Konstitusi Dan Pelaksanaannya di Indonesia, (Jakarta : Ichtiar Baru Van Hoeve, 1999), hlm. 70
} 
Dasar. ${ }^{19}$ Pada hakikatnya dalam ide kedaulatan rakyat itu, tetap harus dijamin bahwa rakyatlah yang sesungguhnya pemilik negara dengan segala kewenangannya untuk menjalankan semua fungsi kekuasaan negara, baik di bidang legislatif, eksekutif, maupun yudikatif. Dan tentunya UUD Tahun 1945 dengan segala ketentuannya merupakan penjelmaan kedaulatan rakyat, baik yang dilaksanakan secara langsung (direct democracy) maupun yang dilaksanakan secara tidak langsung atau perwakilan (representative democracy) melalui lembaga perwakilan rakyat. Oleh sebab itu pula, organ atau lembaga-lembaga negara yang melaksanakan fungsi kekuasaan negara dianggap melaksanakan amanat kedaulatan rakyat dan tunduk pada kedaulatan rakyat berdasarkan ketentuan Undang-Undang Dasar. Apabila hal ini dihubungkan dengan teori kontrak sosial JJ Rousseau yang menyatakan bahwa kehendak rakyat yang berdaulat itu dapat disalurkan dengan dua cara yaitu, ${ }^{20}$ pertama adalah kehendak seluruh rakyat yang biasa disebut volunte de tous dan yang kedua adalah kehendak umum yang berarti tidak harus semua rakyat atau disebut sebagai volunte generale. Kehendak yang pertama biasa juga disebut sebagai kedaulatan politik dan yang kedua biasa juga disebut sebagai kedaulatan hukum.

Menurut Moh. Kusnardi dan Harmailly Ibrahim dalam paham kedaulatan rakyat (democracy), rakyatlah yang dianggap sebagai pemilik atau pemegang kekuasaan tertinggi dalam suatu negara. ${ }^{21}$ Rakyatlah yang menentukan corak dan bagaimana cara pemerintahan diselenggarakan. Rakyatlah yang menentukan tujuan yang hendak dicapai oleh negara dan pemerintahannya itu. Dalam suatu negara yang kecil, yang jumlah penduduknya sedikit, dan juga dengan luas wilayah yang tidak begitu besar, kedaulatan rakyat yang seperti ini tidak dapat berjalan dengan semurni-murninya atau tidak berjalan dengan sepenuhnya. Apalagi di negaranegara dengan jumlah penduduk yang besar dan ditambah lagi dengan luas wilayah yang besar pula, sangat tidak mungkin untuk menghimpun pendapat rakyat seorang demi seorang untuk menentukan jalannya pemerintahan. Ditambah lagi dalam konteks masyarakat modern seperti sekarang ini dimana kehidupan sudah sangat berkembang dinamis dan kompleks, masing-masing rakyat memiliki ragam pekerjaan dan spesialisasi yang perbedaannya sudah semakin tajam, termasuk juga perbedaan tingkat kecerdasan antar individual dalam masyarakat. Hal-hal seperti ini menyebabkan kedaulatan rakyat tidak dapat dilakukan secara murni, namun dengan tetap dalam kondisi bahwa kedaulatan rakyat itu harus ditegakkan, kompleksitas seperti ini berujung pada pembenaran bahwa kedaulatan rakyat itu dilaksanakan dengan melalui sistem perwakilan (representation).

Kedaulatan rakyat diwujudkan dalam tiga cabang kekuasaaan yang tercermin dalam Majelis Permusyawaratan Rakyat yang terdiri atas Dewan Perwakilan Rakyat dan Dewan Perwakilan Daerah sebagai pemegang kekuasaan legislatif, Presiden dan Wakil Presiden sebagai pemegang kekuasaan eksekutif, dan Mahkamah Agung dan Mahkamah Konstitusi sebagai pemegang kekuasaan yudikatif. Dalam menentukan kebijakan pokok pemerintahan dan mengatur ketentuan-ketentuan hukum berupa Undang-Undang Dasar dan undang-undang dan

${ }^{19}$ Jimly Asshiddiqie (2), Konstitusi dan Konstitusionalisme Indonesia, (Jakarta : Konstitusi Press, 2005), hlm. 58.

${ }^{20}$ Jimly Asshiddiqie (1), Op.Cit., hlm.77

${ }^{21}$ Moh. Kusnardi dan Harmailly Ibrahim, Pengantar Hukum Tata Negara, (Jakarta : 1981, Pusat Studi HTN UI) , hlm. 328 
juga dalam menjalankan fungsi pengawasan terhadap jalannya pemerintahan, dilangsungkanlah suatu perlembagaan kedaulatan rakyat melalui pemilu berdasarkan sistem perwakilan yang menghadirkan Dewan Perwakilan Rakyat dan Dewan Perwakilan Daerah. Bahkan juga di daerah-daerah provinsi dan kabupaten/kota, perlembagaan kedaulatan rakyat itu disalurkan melalui sistem perwakilan sehingga menghadirkan Dewan Perwakilan Rakyat Daerah yang juga diisi melalui pemilihan umum. ${ }^{22}$

Pemilu dilaksanakan dengan asas langsung, umum, bebas, rahasia, jujur, dan adil setiap lima tahun sekali. ${ }^{23}$ Ada beberapa alasan mengapa sangat penting pemilihan umum untuk dilaksanakan secara berkala in casu setiap lima tahun sekali $:{ }^{24}$ Pertama, pendapat atau aspirasi rakyat tidak akan selalu sama untuk jangka waktu yang panjang dalam artian bahwa kondisi kehidupan rakyat itu bersifat dinamis sehingga aspirasi mereka akan aspek kehidupan bersama juga akan berubah-ubah seiring dengan berjalannya waktu. Mungkin saja terjadi dalam jangka waktu tertentu rakyat menghendaki agar corak dan jalannya pemerintahan harus berubah, hal ini dapat kita pahami dengan melihat proses amandemen UUD Tahun 1945 dan dihubungkan dengan teori resultante dari K.C. Wheare yang menyatakan bahwa kondisi masyarakat pada suatu masa tertentu memiliki aspek pengaruh yang sangat besar terhadap pembentukan konstitusi. Kedua, disamping pendapat rakyat dapat berubah-ubah dari waktu ke waktu, kondisi kehidupan bersama dalam masyarakat dapat pula berubah, baik karena dinamika internasional maupun karena dinamika dalam negeri sendiri, baik karena faktor internal manusia maupun karena faktor eksternal manusia. Ketiga, perubahan-perubahan aspirasi dapat juga disebabkan karena pertambahan jumlah penduduk dan rakyat yang dewasa. Mereka itu, terutama para pemilih baru (new voters) atau pemilih pemula belum tentu memiliki sikap yang sama dengan orang tua mereka sendiri. Dan keempat, pemilihan umum perlu diadakan secara teratur dengan maksud untuk menjamin terjadinya pergantian kepemimpinan negara, baik di cabang kekuasaan eksekutif maupun di cabang kekuasaan legislatif. Untuk menjamin siklus kekuasaan yang besifat teratur itu diperlukan mekanisme pemilihan umum yang diselenggarakan secara berkala sehingga demokrasi dapat terjamin, dan pemerintahan yang sungguh-sungguh mengabdi kepada kepentingan seluruh rakyat dapat benar-benar bekerja efektif dan efisien. Jadi, dengan adanya jaminan sistem demokrasi yang beraturan itulah kesejahteraan dan keadilan dapat diwujudkan dengan baik.

Affan Gafar mengajukan 5 (lima) parameter untuk sebuah pemilihan umum yang ideal. ${ }^{25}$ Pertama, pemilihan umum yang akan datang haruslah diselenggarakan dengan cara yang demokratis sehingga memberikan peluang bagi semua partai dan calon legislatif yang terlibat untuk berkompetisi secara fair dan jujur. Rekayasa dan manipulasi yang sangat mewarnai penyelenggaraan pemilu masa lampau jangan sampai terulang lagi. Kedua, pemilihan umum haruslah menciptakan MPR/DPR, DPRD Provinsi dan DPRD Kabupaten/Kota yang lebih baik, lebih berkualitas, dan memiliki akuntabilitas politik yang tinggi. Ketiga,

${ }^{22}$ Jimly Asshiddiqie (2), Ibid, hlm. 59.

${ }^{23}$ Republik Indonesia (2), Op. Cit. Pasal 22E ayat (1)

${ }^{24}$ Jimly Asshiddiqie (3), Pengantar Ilmu Hukum Tata Negara, (Jakarta : Sekretariat Jenderal dan Kepaniteraan Mahkamah Konstitusi, 2006), hlm. 171

${ }_{25}$ Affan Gafar, Politik Indonesia: Transisi Menuju Demokrasi, (Yogyakarta : Pustaka Pelajar, 2000) hlm. 251- 255. 
derajat keterwakilan, artinya bahwa anggota MPR/DPR yang dibentuk melalui pemilihan umum haruslah memiliki keseimbangan perwakilan, baik antara wakil Jawa maupun luar Jawa atau antara pusat dengan daerah. Keempat, peraturan perundang-undangan pemilu haruslah tuntas. Kelima, pelaksanaan pemilu hendaknya bersifat praktis, artinya tidak rumit dan gampang dimengerti oleh kalangan masyarakat banyak.

Jadi pemilu adalah tidak lain sebagai cara untuk memilih wakil-wakil rakyat secara demokratis. Oleh sebab itu, bagi sebuah negara yang mendeklarasikan sebagai negara demokratis, maka pemilu yang demokratis itu merupakan ciri penting dan harus dilaksanakan dalam waktu-waktu yang tertentu. Pengertian pemilu sendiri menurut UUD Tahun 1945 diatur dalam Pasal 22E ayat (2) dimana Pemilihan Umum diselenggarakan untuk memilih anggota Dewan Perwakilan Rakyat, Dewan Perwakilan Daerah, Presiden dan Wakil Presiden, dan Dewan Perwakilan Rakyat Daerah. ${ }^{26}$ Para wakil-wakil rakyat tersebut bertindak atas nama rakyat dan merekalah yang kemudian menentukan corak dan jalannya pemerintahan suatu negara, serta tujuan apa yang hendak dicapai baik dalam jangka waktu yang pendek maupun dalam waktu yang panjang. Hal seperti yang dikatakan Rousseau sebagai pelaksanaan kedaulatan rakyat melalui kehendak hukum (volunte

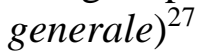

Setelah perubahan UUD Tahun 1945 terjadi pergeseran dalam memaknai kedaulatan rakyat. Sebelum perubahan UUD Tahun 1945 kedaulatan ditangan rakyat dan dilaksanakan sepenuhnya oleh MPR. Setelah perubahan justru terjadi perubahan fundamental dimana kedaulatan ditangan rakyat dan dilaksanakan menurut undang-undang ${ }^{28}$. Ini berarti rakyat sebagai sumber kekuasaan, rakyat pula yang secara langsung ataupun tidak langsung menjadi pengurus atau penyelenggara negara dan pada akhrinya untuk kepentingan seluruh rakyat pulalah penyelenggaraan negara itu sesungguhnya dimaksudkan. ${ }^{29}$ Konsep ini berbeda dengan pelaksana kedaulatan adalah MPR sebelum perubahan UUD Tahun 1945, karena pelaku kedaulatan setelah perubahan UUD Tahun 1945 bukan hanya MPR tetapi juga Presiden, DPR, DPD, dan bahkan lembaga-lembaga peradilan seperti MA dan MK. Hanya saja, ada Lembaga yang mendapatkan mandat dan pendelegasian kekuasaan secara langsung melalui pemilu seperti MPR, DPR, DPD, serta presiden; dan adapula yang mendapatkan kekuasaan melalui system perwakilan seperti MA dan MK.

Perubahan ihwal kedaulatan rakyat ini juga dapat dilihat pada pergeseran kewenangan antara presiden dan DPR sebagai hasil dari pemilu. Sebelum perubahan UUD Tahun 1945 kekuasaan membentuk undang-undang dipegang oleh presiden dengan persetujuan DPR. Sangat berbeda dengan setelah perubahan UUD Tahun 1945 dimana DPR sebagai pemegang kekuasaan membentuk undangundang. Walaupun pembahasan harus dilakukan secara bersama dan harus mendapat persetujuan bersama namun pemegang asli kekuasaan membentuk undang-undang itu pada dasarnya telah bergeser dari tangan presiden kepada DPR.

${ }^{26}$ Republik Indonesia (2), Op. Cit. Pasal 22E ayat (1)

27 Jean Jacques Rousseau, Du Contract Social (Perjanjian Sosial), (Jakarta : Visimedia, 2009), hlm. 46.

${ }^{28}$ Republik Indonesia (2), Op. Cit. Pasal 1 ayat (2)

${ }^{29}$ Jimly Asshiddiqie (4), Komentar Atas Undang-Undang Dasar Negara Republik Indonesia Tahun 1945, (Jakarta : Sinar Grafika, 2013), Pasal 1 ayat (2) hlm.10 
Penjelmaan kedaulatan rakyat pada UUD Tahun 1945 setelah perubahan berarti penjelmaan kedaulatan rakyat itu dalam ketentuan-ketentuan UUD Tahun 1945 sebagai implikasi yuridis ketentuan Pasal 1 ayat (2) UUD Tahun 1945, bukan seperti sebelum perubahan ${ }^{30}$ yang dilakukan sepenuhnya oleh MPR. UUD Tahun 1945 setelah perubahan menetukan bahwa semua lembaga atau organ negara melaksanakan kedaulatan rakyat, tidak hanya MPR saja sebagai lembaga tertinggi negara seperti sebelumnya.

Hasil dari pemilu itulah yang kemudian mengisi jabatan-jabatan kelembagaan negara yang menjalankan kedaulatan rakyat dalam bentuk kedaulatan hukum. Hanya saja dalam proses menjalankan kedaulatan rakyat itu, semua lembaga negara haruslah tunduk pada ketentuan-ketentuan Undang-Undang Dasar sebagai implikasi dari supremasi konstitusi sesuai dengan ketentuan Pasal 1 ayat (2) UUD Tahun 1945. Tidak hanya itu saja, segala ketentuan yang berada dalam UUD Tahun 1945 sejatinya adalah amanat pelaksanaan kedaulatan rakyat namun tetap tidak dapat bertentangan dengan kedaulatan rakyat itu sendiri. Artinya apabila rakyat menghendaki untuk merubah ketentuan-ketentuan dalam UUD Tahun 1945, maka kehendak rakyat ini harus dipandang sebagai kehendak hukum ataupun kedaulatan di bidang hukum (volunte general) yang harus disalurkan dan tidak boleh dikesampingkan karena UUD Tahun 1945 juga telah memberi peluang untuk melakukan perubahan terhadapnya. Inilah penegasan kembali terhadap pelaksanaan sistem konstitusional berdasarkan Undang-Undang Dasar, yaitu pelaksanaan kedulatan rakyat yang disalurkan dan diselenggarakan menurut prosedur konstitusional yang ditetapkan dalam hukum dan konstitusi (constitutional democracy). ${ }^{31}$ Ataupun disebutkan sebagai negara demokrasi yang berdasarkan hukum dan negara hukum yang demokratis, beriringannya konsep demokrasi dan nomokrasi. Ihwal ini dikarenakan kedaulatan rakyat itu terwujud juga dalam hukum selain terwujud juga dalam lembaga-lembaga negara sebagaimana telah diuraikan diatas. Oleh karena itu, lembaga-lembaga tinggi negara yang melaksanakan kedaulatan rakyat secara kehendak hukum (volunte generale) tetap tidak boleh melanggar prinsip kedaulatan rakyat. ${ }^{32}$

Dalam sistem demokrasi modern, legalitas dan legitamasi pemerintahan merupakan faktor yang sangat penting. Di satu pihak, suatu pemerintahan haruslah terbentuk berdasarkan ketentuan hukum dan konstitusi sehingga dapat dikatakan memiliki legalitas. Di lain pihak, pemerintahan itu juga harus legitimate, dalam arti bahwa di samping legal, ia juga harus dipercaya. Tentu akan timbul keragu-raguan, apabila suatu pemerintah menyatakan diri bahwa mereka berasal dari rakyat dan dapat disebut sebagai pemerintahan yang demokrasi, padahal pembentukannya tidak berasal dari pemilu. Artinya, setiap pemerintahan yang demokratis yang mengaku berasal dari rakyat, memang diharuskan sesuai dengan hasil pemilihaan umum sebagai ciri yang penting atau pilar yang pokok dalam sistem demokrasi modern. Jimly Asshiddiqie kemudian menegaskan bahwa, pemilihan umum dapat dikatakan sebagai syarat yang mutlak bagi negara demokrasi, yaitu untuk melaksanakan kedaulatan rakyat. ${ }^{33}$ Dan melalui pemilulah rakyat dapat terlibat dalam penentuan atau pengambilan keputusan mengenai jalannya pemerintahan

\footnotetext{
${ }^{30}$ Jimly Asshiddiqie (1), Op.Cit., hlm.76.

${ }^{31}$ Jimly Asshiddiqie (2), Op.Cit., hlm. 58.

${ }^{32}$ Jimly Asshiddiqie (1), Op.Cit., hlm. 81.

${ }^{33}$ Jimly Asshiddiqie (3), Ibid, hlm. 417.
} 
setelah pemilu. Karena perlu ditegaskan lagi bahwa demokrasi itu merupakan suatu sistem politik, ${ }^{34}$ dimana di dalamnya mengikutsertakan rakyat atau warga dalam pengambilan keputusan, dan wujud pelaksanaan atau implementasi demokrasi adalah pemilihan umum. Dan tentunya pelaksanaan pemilihan umum yang langsung, umum, bebas, rahasia, jujur dan adil. ${ }^{35}$

\section{Kedaulatan Rakyat Dalam UUD Tahun 1945}

Pengertian atau maksud kedaulatan rakyat dalam UUD Tahun 1945, dapat pula dikatakan berbeda dengan maksud atau pengertian kedaulatan rakyat di negara-negara liberal pada umumnya. Sebabnya adalah kedaulatan rakyat Indonesia menurut UUD Tahun 1945 tidak hanya menyangkut bidang politik, tetapi juga kedaulatan rakyat di bidang ekonomi dan bahkan sosial. ${ }^{36}$ Menurut Soekarno, prinsip ini disebutkan sebagai sosio-demokrasi, demokrasi yang berdiri di kedua kakinya. Sosio-demokrasi menurutnya adalah mencakup juga demokrasi ekonomi tidak hanya demokrasi politik. Ditambahkannya pula bahwa pada bentuk demokrasi seperti ini rakyat menjadi berdaulat dalam bidang politik dan juga dalam bidang ekonomi. Itu juga sebabnya maka UUD Tahun $1945,{ }^{37}$ selain memuat ketentuanketentuan dasar mengenai sistem politik juga memuat dasar-dasar mengenai sistem ekonomi. Dengan kata lain, UUD Tahun 1945 sebagai hukum dasar dan hukum tertinggi dalam ketatanegaraan Republik Indonesia harus menjadi acuan dan pegangan bagi penyelenggara negara dalam menentukan kebijakan-kebijakan dalam rangka menjalankan tugas kenegaraan dan pemerintahan. Kebijakan politik, kebijakan ekonomi, dan bahkan kebijakan sosial budaya harus mengacu pada ketentuan hukum dasar atau ketentuan hukum tertinggi yaitu UUD Tahun 1945. UUD Tahun 1945 adalah cerminan kehendak politik seluruh rakyat yang berdaulat dalam negara Republik Indonesia. Kedaulatan rakyat itu tidak hanya menyangkut aspek politik kehidupan bernegara, tetapi juga dalam bidang ekonomi, sosial, dan budaya dalam bernegara. Karena itu dikatakan bahwa Indonesia menjalankan paham demokrasi politik dan demokrasi ekonomi. ${ }^{38}$

Suatu hal yang lazim dipahami bahwa UUD Tahun 1945 saja menganut ajaran kedaulatan rakyat meskipun lazim pula para ahli Hukum Tata Negara yang menyatakan bahwa selain ajaran kedaulatan rakyat juga terdapat ajaran kedaulatan lain dalam UUD Tahun 1945, misalnya Ismail Sunny yang menyatakan bahwa UUD Tahun 1945 menganut tiga ajaran kedaulatan sekaligus yaitu ajaran kedaulatan tuhan, kedaulatan rakyat, dan kedaulatan hukum. ${ }^{39}$ Hal ini secara tegas dirumuskan dalam Pasal 1 ayat (2) UUD Tahun 1945 yang menyatakan "Kedaulatan berada di tangan rakyat dan dilaksanakan menurut Undang-Undang Dasar". 40

${ }^{34}$ Soehino, Hukum Tata Negara : Perkembangan Pengaturan dan Pelaksanaan Pemilihan Umum di Indonesia, (Yogyakarta : BPFE-Yogyakarta, 2010), hlm.74.

${ }^{35}$ Republik Indonesia (2), Op.Cit., Pasal 22E ayat (1)

${ }^{36}$ Jimly Asshiddiqie (5), Pokok-Pokok Hukum Tata Negara Indonesia Pasca Reformasi, (Jakarta : PT. Buana Indah Populer). hlm. 296.

${ }^{37}$ Loc. Cit.

${ }^{38}$ Jimly Asshiddiqie (5), Ibid, hlm. 292.

${ }^{39}$ Jimly Asshiddiqie (1), Op.Cit., hlm. 61.

${ }^{40}$ Republik Indonesia (2), Op. Cit. Pasal 1 ayat (2) 
Dalam proses perubahan UUD Tahun 1945 terjadi pergulatan pemikiran tentang gagasan kedaulatan rakyat. Pergulatan pemikiran tersebut berujung dengan diubahnya ketentuan Pasal 1 ayat (2) UUD Tahun 1945. Awalnya, Pasal 1 ayat (2) UUD Tahun 1945 berbunyi "Kedaulatan adalah ditangan rakyat, dan dilakukan sepenuhnya oleh Majelis Permusyawaratan Rakyat". ${ }^{41}$ Kemudian diubah pada saat perubahan ketiga UUD Tahun 1945 sehingga rumusannya menjadi "Kedaulatan berada di tangan rakyat dan dilaksanakan menurut Undang-Undang Dasar". ${ }^{2}$

MPR yang pada mulanya dipahami sebagai pemegang mandat sepenuhnya dari rakyat atau pemegang kedaulatan rakyat yang tertinggi, ${ }^{43}$ bergeser ke arah pemahaman bahwa MPR tidak lagi sebagai pemegang mandat tunggal yang tertinggi, melainkan mandat itu dilaksanakan berdasarkan Undang-Undang Dasar. Dengan demikian, mandat rakyat dijalankan oleh cabang-cabang kekuasaan negara berdasarkan UUD, termasuk oleh MPR sebagai salah satu lembaga penyelenggara kekuasaan negara. Alasan perubahan ini menurut Jimly Asshiddiqie dikarenakan rumusan Pasal 1 ayat (2) sebelum perubahan memuat ketentuan yang tidak jelas, dengan adanya ungkapan “...dilakukan sepenuhnya oleh Majelis Permusyawaratan Rakyat" maka ada yang menafsirkan bahwa hanya MPR sajalah yang melakukan kedaulatan rakyat sehingga DPR yang merupakan wakil rakyat dipandang tidak melaksanakan kedaulatan rakyat. ${ }^{44}$

Perubahan ini menurut Jimly Asshiddiqie untuk mempertegas bahwa $:^{45}$ (a) kedaulatan atau kekuasaan tertinggi itu berada dan berasal atau bersumber dari rakyat seluruhnya; (b) kedaulatan rakyat tersebut harus harus pula diselenggarakan atau dilaksanakan menurut ketentuan UUD sendiri; dan (c) organ pelaku atau pelaksana prinsip kedaulatan rakyat itu tidak terbatas hanya MPR saja, melainkan semua lembaga negara adalah juga pelaku langsung atau tidak langsung kekuasaan yang bersumber dari rakyat yang berdaulat tersebut. DPR adalah pelaku kedaulatan rakyat di bidang pembentukan undang-undang, sedangkan presiden dan wakil presiden adalah pelaksana kedaulatan rakyat di bidang pemerintahan negara, Mahkamah Agung, Mahkamah Konstitusi, dan Badan Pemeriksa Keuangan yang juga dipilih oleh rakyat secara tidak langsung dapat pula disebut sebagai pelaksana kedaulatan rakyat di bidang tugasnya masing-masing. ${ }^{46}$

Perubahan ketentuan Pasal 1 ayat (2) UUD Tahun 1945 ini menunjukan terjadinya perubahan gagasan yang begitu mendasar tentang kedaulatan rakyat dalam UUD Tahun 1945. Terjadi pergeseran yang sangat fundamental tentang siapa sebenarnya yang bertindak sebagai pemegang supremasi atau kekuasaan tertinggi. Sebagaimana dikemukakan Soewoto Mulyosudarmo, perubahan Pasal 1 ayat (2) UUD Tahun 1945 merupakan perubahan menuju sebuah kondisi yang mencerminkan keadaan yang sebenarnya tentang pengaturan kekuasaan tertinggi. ${ }^{47}$ Di mana pemilik kekuasaan tertinggi dalam negara adalah rakyat yang

\footnotetext{
${ }^{41}$ Republik Indonesia (1), Op. Cit., Pasal 1 ayat (2)

${ }^{42}$ Republik Indonesia (2), Op. Cit. Pasal 1 ayat (2)

${ }^{43}$ Soewoto Mulyosudarmo, Pembaharuan Ketatanegaraan Melalui Perubahan Konstitusi, (Malang : Asosiasi Pengajar HTN dan HAN dan In-TRANS, 2004), hlm. 3

${ }^{44}$ Jimly Asshiddiqie (6), Implikasi Perubahan UUD Tahun 1945 Terhadap Pembangunan Hukum Nasional, Sambutan Pada Seminar Pengkajian Hukum Nasional (SPHN) Oleh Komisi Hukum Nasional (KHN) Republik Indonesia, Jakarta, 21 November 2005.

${ }^{45}$ Ni'matul Huda, Op. Cit., hlm. 158

${ }^{46}$ Loc. Cit.

${ }^{47}$ Soewoto Mulyosudarmo, Op. Cit., hlm. 4.
} 
pelaksanaannya sesuai dengan Undang-Undang Dasar. Perubahan gagasan kedaulatan dalam UUD Tahun 1945 sekaligus juga diiringi dengan perubahan terhadap cara rakyat memberikan mandat terhadap penyelenggara kekuasaan negara. Salah satu contoh yang dapat dikemukakan bahwa Presiden sebagai penyelenggara salah satu cabang kekuasaan negara pada awalnya dipilih oleh MPR. Sedangkan berdasarkan UUD Tahun 1945 setelah perubahan, Presiden dipilih langsung oleh rakyat, tidak lagi oleh MPR. Pemilihan presiden langsung oleh rakyat menandai presiden tidak bertanggung jawab kepada MPR, melainkan bertanggung jawab kepada rakyat. Ihwal ini sebagai pertanda UUD Tahun 1945 setelah perubahan menganut prinsip presidensial dan mereduksi sistem presidensial yang dianut pada UUD Tahun 1945 sebelum perubahan. ${ }^{48}$

Sebagai wujud dari ide kedaulatan rakyat, dalam sistem demokrasi harus dijamin bahwa rakyat terlibat penuh dalam merencanakan, mengatur, melaksanakan, dan melakukan pengawasan serta menilai pelaksanaan fungsi-fungsi kekuasaan. Pelaksanaan keterlibatan penuh rakyat tersebut haruslah diorganisasikan menurut Undang-Undang Dasar sesuai dengan dengan ketentuan UUD Tahun 1945, tidak lagi diorganisasikan melalui institusi kenegaraan Majelis Permusyawaratan Rakyat layaknya ketentuan UUD Tahun 1945 sebelum perubahan. Perbedaan yang terjadi setelah perubahan itu sangat jelas dan prinsipil. ${ }^{49}$ Pertama, kedaulatan yang berada di tangan rakyat itu sekarang tidak lagi dilembagakan hanya pada satu subjek (ordening subject), MPR sebagai penjelmaan tunggal lembaga negara. Dalam rumusan yang baru, semua lembaga negara baik secara langsung ataupun tidak langsung juga dianggap sebagai penjelmaan dan dibentuk dalam rangka pelaksanaan kedaulatan rakyat. Kedua, pengharusan pelaksanaan tugas menurut ketentuan Undang-Undang Dasar tidak hanya satu lembaga saja, yakni MPR, melainkan semua lembaga negara diharuskan bekerja menurut ketentuan Undang-Undang Dasar.

Dalam rumusan yang baru, subjek pemegang kedaulatan rakyat tidak lagi terkait hanya dengan satu subjek, maka berarti, semua lembaga negara atau jabatan publik baik secara langsung atau tidak langsung juga dianggap sebagai penjelmaan dan dibentuk dalam rangka pelaksanaan kedaulatan rakyat. Secara langsung penjelmaan dan pelaksanaan kedaulatan rakyat itu adalah melalui pemilu langsung untuk menetukan pemegang jabatan publik pada suatu lembaga negara sedangkan secara tidak langsung adalah dengan perantara wakil rakyat dalam hal ini Dewan Perwakilan Rakyat.

Oleh karena semua lembaga negara atau jabatan publik pada hakikatnya adalah jabatan yang memperoleh legitimasi dari rakyat yang berdaulat, maka bukan saja tugas dan wewenang jabatan itu harus diselenggarakan menurut UndangUndang Dasar, tetapi juga harus dipertanggungjawabkan kepada rakyat melalui prinsip akuntabilitas, transparansi, dan cara kerja yang partisipatoris. Setiap warga negara harus mendapatkan akses yang seluas-luasnya terhadap kinerja lembagalembaga negara, dan secara berkala lembaga-lembaga negara yang bersangkutan diharuskan menyampaikan laporan terbuka kepada masyarakat, dan yang tidak kalah pentingnya adalah kebebasan pers untuk mendapatkan informasi dan memberikan informasi itu kepada masyarakat luas. ${ }^{50}$

${ }^{48}$ Jimly Asshiddiqie (2), Op. Cit., hlm. 162

49 Jimly Asshiddiqie (5), Op. Cit., hlm. 292.

${ }^{50}$ Jimly Asshiddiqie (5), Ibid, hlm. 295. 
Setelah perubahan UUD Tahun 1945 terdapat pula perubahan ihwal pemilihan presiden dan wakil presiden. Sebelum perubahan presiden dan wakil presiden dipilih oleh MPR namun setelah perubahan terjadi sangat radikal dimana pemilihan presiden dan wakil presiden dipilih langsung oleh rakyat. Kewenangan untuk memilih presiden dan wakil presiden yang selama ini dipilih oleh MPR dimana MPR dalam melaksanakan mandat dari rakyat kini rakyat langsung yang memberikan mandat itu kepada presiden dan wakil presiden tanpa melalui sebuah lembaga perwakilan (MPR).

Pemilihan presiden secara langsung merupakan langkah untuk pemurnian (purifikasi) sistem presidensial. Menurut Saldi Isra mereformasi model sistem pemilihan presiden dan wakil presiden dari pemilihan model sistem perwakilan (pemilihan oleh MPR) menjadi pemilihan secara langsung oleh rakyat. ${ }^{51}$ Sistem pemilihan yang dilakukan oleh MPR cenderung mengarah Indonesia menganut sistem parlementer. UUD Tahun 1945 sebelum perubahan memang tidak secara tegas menyatakan Indonesia menganut sistem parlementer namun dari relasi hubungan antara eksekutif (presiden) dengan legaslatif (MPR) memperkuat indikasi sistem parlementer itu. Secara tegas Jimly Asshiddiqie menjelaskan salah satu ciri sistem parlementer ialah adanya pertanggungjawaban kabinet kepada parlemen yang mengakibatkan parlemen dapat membubarkan atau menjatuhkan mosi tidak percaya kepada kabinet (presiden). ${ }^{52}$ Relasi hubungan yang demikian terjadi karena presiden dipilih dan diangkat oleh MPR sehingga presiden bertanggung jawab kepada MPR selaku pemegang pelaksana kedaulatan rakyat.

Secara substantif ini kelemahan yang terdapat dalam UUD Tahun 1945. UUD Tahun 1945 sebelum perubahan sangat minim mengatur prinsip checks and balances sehingga UUD Tahun 1945 dapat dikatakan executive heavy yang dalam istilah Soepomo disebutkan concentration of power and responsibility upon the president. ${ }^{53}$ Namun demikian, setelah perubahan UUD Tahun 1945 Indonesia dapat menerapkan sistem presidensial murni dengan melakukan pemilihan presiden secara langsung. Menurut Stepan dan Skach, prinsip saling mandiri dalam sistem presidensial terlihat dari kekuasaan legislatif dan eksekutif yang memiliki sumber legitimasi langsung dari rakyat melalui pemilihan umum. ${ }^{54}$ Dengan kata lain, pemilihan legislatif dan pemilihan eksekutif dilakukan pada dua pemilu (dual democratic legitimacy) yang menimbulkan prinsip mutual independence. ${ }^{55}$

Apabila dibaca semua substansi hasil perubahan UUD Tahun 1945 terutama yang terkait langsung dengan pemegang kekuasaan legislatif dan pemegang kekuasaan eksekutif serta relasi keduanya, pilihan tetap mempertahankan sistem presidensial diikuti upaya mengikis karakter sistem parlementer. Dalam Bahasa yang lebih sederhana, langkah menata sistem pemerintahan dilakukan dengan cara pemurnian sistem presidensial. Langkah menuju pemurnian dilakukan berupa $:^{56}$ (a) mengubah proses pemilihan presiden dan wakil presiden; (b) menata ulang posisi MPR sebagai lembaga tertinggi negara dan menghapus pertanggungjawaban

${ }^{51}$ Saldi Isra (2), Sistem Pemerintahan Indonesia : Pergulatan Ketatanegaraan Menuju Sistem Pemerintahan Presidensial, (Depok : Rajawali Pers, 2019), hlm. 150

${ }^{52}$ Fitra Arsil, Teori Sistem Pemerintahan : Pergeseran Konsep dan Saling Kontribusi Antar Sistem Pemerintahan di Berbagai Negara, (Depok : Rajawali Pers, 2017), hlm. 20

${ }^{53}$ Ni'matul Huda, Op. Cit. hlm. 150

${ }^{54}$ Fitra Arsil, Op. Cit. hlm. 69

${ }^{55}$ Loc. Cit.

${ }^{56}$ Saldi Isra (1), Op. Cit. hlm. 9 
presiden kepada Lembaga perwakilan, in casu keharusan presiden untuk bertanggung jawab kepada MPR; dan (c) memperjelas mekanisme pemberhentian (pemakzulan) presiden/wakil presiden sebelum habis masa jabatan atau ditengah jabatan.

Walaupun demikian, pencalonan pasangan calon presiden dan wakil presiden bukan berarti dibuka sebebas-bebasnya. Konstitusi mengatur pancalonan presiden dan wakil presiden diusulkan oleh partai politik atau gabungan partai politik dengan persyaratan yang diatur dalam undang-undang. ${ }^{57}$ Pengaturan mengenai persyaratan pencalonan presidan dan wakil presiden ini sepenuhnya menjadi kebijakan politik terbuka (open legal policy) yang dimiliki oleh DPR. DPR sebagai lembaga pemegang kewenangan legislasi bersama presiden mengatur dalam undang-undang ihwal syarat suara minimal bagi partai atau gabungan partai untuk mencalonkan presiden dan wakil presiden (presidential threshold) yang besarannya dapat dilihat pada matriks dibawah ini :

\begin{tabular}{|c|c|c|}
\hline Pemilu & UU & $\mathrm{PT}$ \\
\hline 2004 & $\begin{array}{l}\text { UU No. } 23 \text { Tahun } 2003 \\
\text { tentang Pemilihan } \\
\text { Umum Presiden dan } \\
\text { Wakil Presiden }^{58}\end{array}$ & $\begin{array}{l}15 \% \text { dari jumlah kursi DPR atau } \\
20 \% \text { dari perolehan suara sah } \\
\text { secara nasional dalam pemilu } \\
\text { anggota DPR }\end{array}$ \\
\hline 2009 & $\begin{array}{l}\text { UU No. } 42 \text { Tahun } 2008 \\
\text { tentang Pemilihan } \\
\text { Umum Presiden dan } \\
\text { Wakil Presiden } \\
\text { W9 }\end{array}$ & $\begin{array}{l}20 \% \text { dari jumlah kursi DPR atau } \\
25 \% \text { dari perolehan suara sah } \\
\text { secara nasional dalam pemilu } \\
\text { anggota DPR }\end{array}$ \\
\hline 2014 & $\begin{array}{l}\text { UU No. } 42 \text { Tahun } 2008 \\
\text { tentang Pemilihan } \\
\text { Umum Presiden dan } \\
\text { Wakil Presiden }\end{array}$ & $\begin{array}{l}20 \% \text { dari jumlah kursi DPR atau } \\
25 \% \text { dari perolehan suara sah } \\
\text { secara nasional dalam pemilu } \\
\text { anggota DPR }\end{array}$ \\
\hline 2019 & $\begin{array}{l}\text { UU No. } 7 \text { Tahun } 2017 \\
\text { tentang Pemilihan } \\
\text { Umum }^{61}\end{array}$ & $\begin{array}{l}20 \% \text { dari jumlah kursi DPR atau } \\
25 \% \text { dari perolehan suara sah } \\
\text { secara nasional dalam pemilu } \\
\text { anggota DPR yang didapatkan } \\
\text { pada pemilu sebelumnya yaitu } \\
\text { Pemilu anggota DPR tahun } 2014\end{array}$ \\
\hline
\end{tabular}

Partai politik memiliki peran sentral dalam mencalonkan presiden dan wakil presiden karena konstitusi dengan tegas mengatur pencalonan pasangan calon presiden dan wakil presiden melalui partai politik. Ihwal ini sangat berbeda dengan Pilkada dimana konstitusi tidak mengatur harus menggunakan partai politik sebagai syarat pencalonan kepala daerah. Untuk itu kemudian, Mahkamah Konstitusi

${ }^{57}$ Republik Indonesia (2), Op. Cit. Pasal 6A ayat (2)

${ }^{58}$ Republik Indonesia (3), Undang-Undang No. 23 Tahun 2003 tentang Pemilihan Umum Presiden dan Wakil Presiden Pasal 5 ayat (4)

${ }^{59}$ Republik Indonesia (4)), Undang-Undang No. 42 Tahun 2008 tentang Pemilihan Umum Presiden dan Wakil Presiden Pasal 9

${ }^{60}$ Republik Indonesia (4), Loc. Cit. Pasal 222

${ }^{61}$ Republik Indonesia (5), Undang-Undang No. 7 Tahun 2017 tentang Pemilihan Umum 
memberikan putusan melalui Putusan No. 5/PUU-V/2007 dimana dimungkinkan untuk calon kepala daerah maju secara perseorangan tanpa melalui partai politik.

Walaupun konstitusi mengatur mengenai pemilihan presiden secara langsung, konstitusi juga mengatur mekanisme pemberhentian presiden dan wakil presiden selama masa jabatannya. Konstitusi memberikan ruang bagi pemberhentian presiden dan wakil presiden selama masa jabatan, namun ihwal ini bukanlah suatu hal yang mudah untuk dilakukan. Proses pemberhentian melewati empat tahap dengan melibatkan tiga lembaga negara yaitu DPR, MK, dan MPR. DPR mengajukan sidang Istimewa pemberhentian presiden dan atau wakil presiden kepada MPR dengan terlebih dahulu mengajukan permintaan kepada Mahkamah Konstitusi untuk memeriksa dan mengadili bahwa presiden dan atau wakil presiden telah melakukan pelanggaran hukum berupa berupa pengkhianatan terhadap negara, korupsi, penyuapan, tindak pidana berat lainnya, atau perbuatan tercela maupun apabila terbukti tidak lagi memenuhi syarat sebagai Presiden dan/atau Wakil Presiden. ${ }^{62}$

Pengajuan permintaan DPR kepada MPR hanya dapat dilakukan dengan dukungan sekurang-kurangnya $2 / 3$ dari jumlah anggota DPR yang hadir dalam sidang paripurna yang dihadiri oleh sekurang-kurangnya 2/3 dari jumlah anggota DPR. ${ }^{63}$ Dengan melihat Komposisi DPR pada periode 2004-2009, 2009-2014, 2014-2019, dan 2019-2024 didominasi oleh partai-partai pendukung pemerintah pemberhentian presiden sangat sulit untuk dilakukan seperti terlihat pada tabel di bawah ini :

\begin{tabular}{|l|l|l|}
\hline Periode & Koalisi Pemerintah & Oposisi Pemerintah \\
\hline $2004-2009^{64}$ & Partai Demokrat (57) & PDIP (109) \\
& Partai Golkar (128) & PBR (14) \\
& PKS (45) & PDS (13) \\
& PAN (53) & PPD (4) \\
& PPP (58) & PPDI (1) \\
& PKB (52) & PNI Marhaenisme (1) \\
& PBB (11) & \\
\hline $2009-2014^{65}$ & 426 kursi /75\% & 134 kursi (134\%) \\
& Partai Demokrat (150) & PDIP (95) \\
& Partai Golkar (107) & Partai Gerindra (26) \\
& PKS (57) & Partai Hanura (18) \\
& PAN (46) & \\
& PPP (38) & \\
& PKB (28) & Partai Gerindra (73) \\
\hline $2014-2019^{66}$ & PDIP (109) & \\
\hline
\end{tabular}

${ }^{62}$ Republik Indonesia (2), Pasal 7B ayat (1)

${ }^{63}$ Republik Indonesia (2), Pasal 7B ayat (3)

${ }^{64} \mathrm{https} / / /$ id.m.wikipedia.org/wiki/Pemilihan_umum_legislatif_Indonesia_2004 diakses pada tanggal 13 Juli 2020

${ }^{65}$ https://id.m.wikipedia.org/wiki/Pemilihan_umum_legislatif_Indonesia_2009 diakses pada tanggal 13 Juli 2020

${ }^{66} \mathrm{https}$ ://id.m.wikipedia.org/wiki/Pemilihan_umum_legislatif_Indonesia_2014 diakses pada tanggal 13 Juli 2020 


\begin{tabular}{|l|l|l|}
\hline & Partai Golkar (91) & Partai Demokrat (61) \\
& PKB (47) & \\
& PAN (49) & \\
& PPP (39) & \\
Nasdem (35) & \\
& Partai Hanura (16) & \\
\hline $2019-2024^{67}$ & PDIP (128) & Partai Demokrat (54) \\
& Partai Golkar (85) & PKS (50) \\
& Partai Gerindra (78) & \\
& PKB (58) & \\
& PAN (44) & \\
& PPP (19) & \\
& Nasdem (59) & \\
\hline
\end{tabular}

Dari matriks tersebut dapat diketahui sebaran partai politik pendukung dan oposisi pemerintah relatif tidak berimbang. Pada periode pemerintahan 2004-2009 koalisi pemerintah memiliki 75\% dukungan di parlemen, sedangkan partai oposisi yaitu memiliki 25\% dukungan. Namun, partai oposisi didominasi oleh PDIP yang memiliki kursi yang signifikan yaitu 109 kursi. Partai lain sebagai oposisi seperti PBR, PDS, PPDK, PPDI dan PNI Marhaenisme tidak begitu terlihat perannya karena memiliki kursi yang sangat kecil. Pada periode pemerintahan 2009-2014 koalisi pemerintah memiliki 75\% dukungan di parlemen, sedangan partai oposisi hanya mendapatkan 25\%. Bahkan Partai Golkar yang semula mendukung pasangan Calon Presiden dan Wakil Presiden Jusuf Kalla - Wiranto justru masuk pada pemerintahan SBY - Boediono yang tidak lain adalah lawannya saat pilpres. Pada koalisi pemerintah tahun 2014-2019 terdapat 83\% dukungan di parlemen sedangkan partai oposisi menyisakan $17 \%$. Kenaikan jumlah dukungan parlemen pada koalisi pemerintah Jokowi - JK disebabkan berpindahnya Partai Golkar, PAN dan PPP yang semula sebagai pendukung pasangan calon Prabowo - Hatta. Pada periode pemerintahan 2019-2024 koalisi pemerintah memiliki dukungan 82\% sedangkan partai oposisi hanya menyisakan 18\%. Besarnya koalisi partai pemerintah karena terjadinya perpindahan partai pendukung Prabowo - Sandi yaitu PAN dan Partai Gerindra. Perbandingan kursi yang tidak seimbang ini membuat pengawasan DPR terhadap pemerintah tumpul dan mereduksi budaya kritis parlemen.

Menurut Moh. Mahfud MD salah satu kelemahan dari UUD Tahun 1945 sehingga harus dilakukan perubahan ialah karena tidak adanya mekanisme Checks and Balances. ${ }^{68}$ Kekuasaan eksekutif yang terlalu besar yang tanpa disertai dengan checks and balances yang memadai membuat terciptanya sistem executive heavy, dan itu menguntungkan bagi siapa saja yang mendudki jabatan presiden. ${ }^{69}$ Koalisi pemerintah yang tambun menyebabkan hilangnya daya kritis DPR di dalam

${ }^{67}$ https://id.m.wikipedia.org/wiki/Pemilihan_umum_legislatif_Indonesia_2019 diakses pada tanggal 13 Juli 2020

${ }^{68}$ Moh. Mahfud MD, Demokrasi dan Konstitusi Indonesia : Studi Tentang Interaksi Politik dan Kehidupan Ketatanegaraan, (Jakarta : Rineka Cipta, 2003), hlm. 147

${ }^{69}$ Ni'matul Huda, Op. Cit. hlm. 106 
melakukan fungsi-fungsi yang telah diberikan oleh UUD Tahun 1945 seperti fungsi legislasi, fungsi anggaran, dan fungsi pengawasan. Ihwal ini dapat dipahami karena terjadinya barter kekuasaan antara koalisi di parlemen dengan jabatan di eksekutif seperti Menteri.

Dalam sistem demokrasi yang mulai tumbuh seperti Indonesia, berpindah haluannya partai yang semula berseberangan menjadi partai pendukung pemerintah sebagai suatu hal yang tidak sehat. Di satu sisi ini merupakan sikap tidak jujur partai kepada konstituennya dan disisi lain partai tidak siap untuk tidak berada di pusaran kekuasaan.

Jumlah partai pendukung pemerintah mayoritas di parlemen membuat pemerintah selalu merasa aman dari bahaya pemakzulan. Alih-alih mengajukan pemakzulan justru DPR tak bergeming untuk bersikap kritis kepada pemerintah menggunakan fungsi pengawasan yang dimilikinya. Di masa yang akan datang sangat perlu untuk membuat suatu undang-undang yang mengatur ihwal koalisi dan oposisi. Kedua bagian koalisi dan oposisi harus sama-sama diperhatikan dan dikuatkan sehingga tidak menimbulkan kesan yang satu lebih mulia daripada yang lain.

Terdapatnya pasal pemberhentian presiden menunjukkan bahwa kekuasaan yang dimiliki presiden dan wakil presiden adalah dari rakyat oleh sebab itu rakyat dapat mengambilnya kembali.

Ihwal ini sangat berbeda dengan sebelum perubahan. Sebelum perubahan UUD Tahun 1945 tidak secara lengkap mengatur tentang mekanisme pemberhentian presiden dalam masa jabatannya. Pengaturan pemberhentian presiden diatur dalam Pasal 8 UUD Tahun 1945 dengan alasan jika presiden mangkat, berhenti, diberhentikan, atau tidak dapat melakukan kewajibannya dalam masa jabatannya dan digantikan oleh wakil presiden sampai habis masa jabatannya.

Tidak jelasnya mekanisme pemberhentian presiden bukan berarti presiden tidak dapat dimintai pertanggungjawaban dalam menyelenggarakan kekuasaan pemerintahan negara. Hal itu karena sistem pemerintahan menurut UUD Tahun 1945 menganut prinsip kedaulatan rakyat, kekuasaan tertinggi ada pada MPR, maka presiden yang dipilih MPR, harus tunduk dan bertanggung jawab pada MPR. Logikanya, MPR setiap saat dapat memakzulkan presiden, manakala presiden tidak dapat mempertanggungjawabkan pelaksanaan kekuasaan pemerintahan negara di hadapan MPR.

Pelaksanaan pemberhentian presiden ini diperjelas dalam Ketatapan (Tap) MPR No. VI/MPR/1973, yang kemudian diubah dengan Tap MPR No. III/MPR/1978 tentang tentang Kedudukan dan Hubungan Tata-Kerja Lembaga Tertinggi Negara dengan/atau Antar Lembaga-Lembaga Tinggi Negara, Pasal 4 huruf c menyatakan presiden dapat diberhentikan apabila presiden memenuhi kategori sungguh-sungguh melanggar haluan negara ${ }^{70}$ sehingga muncul kewajiban presiden yang diatur dalam Pasal 5 ayat (2) yaitu presiden wajib memberikan pertanggungjawaban di hadapan sidang Istimewa Majelis yang khusus diadakan untuk meminta pertanggungjawaban Presiden dalam pelaksanaan haluan Negara

${ }^{70}$ Republik Indonesia (6), Ketatapan MPR No. III/MPR/1978 tentang Kedudukan dan Hubungan Tata-Kerja Lembaga Tertinggi Negara dengan/atau Antar Lembaga-Lembaga Tinggi Negara Pasal 4 huruf c 
yang ditetapkan oleh Undang-undang dasar atau Majelis Permusyawaratan Rakyat. ${ }^{71}$

Tap MPR No. III /MPR/1978 juga mengatur mengenai prosedur pemberhentian presiden yang terdapat pada Pasal 7 yaitu $:^{.72}$

(1) Dewan Perwakilan Rakyat yang seluruh Anggotanya adalah Anggota Majelis berkewajiban senantiasa mengawasi tindakan-tindakan Presiden dalam rangka pelaksanaan Haluan Negara.

(2) Apabila Dewan Perwakilan Rakyat menganggap Presiden sungguh melanggar Haluan Negara, maka Dewan Perwakilan Rakyat menyampaikan memorandum untuk mengingatkan Presiden.

(3) Apabila dalam waktu tiga bulan Presiden tidak memperhatikan memorandum Dewan Perwakilan Rakyat tersebut pada ayat (2) pasal ini, maka Dewan Perwakilan Rakyat menyampaikan memorandum yang kedua.

(4) Apabila dalam waktu satu bulan memorandum yang kedua tersebut pada ayat (3) pasal ini, tidak diindahkan oleh Presiden, maka Dewan Perwakilan Rakyat dapat meminta Majelis mengadakan Sidang Istimewa untuk meminta pertanggungjawaban Presiden.

Namun prosedur pemberhentian presiden dalam Tap MPR No. III/MPR/1978 kurang memiliki kepastian hukum dalam pelaksanaannya. Dalam ayat (1) memiliki batasan yang sangat luas seperti tindakan yang seperti apakah yang harus diawasi DPR? Ihwal ini tidak memiliki pengaturan yang jelas bagaimana mekanisme pengawasan yang harus dilakukan oleh DPR sehingga muncul pemberhentian presiden. Dalam ayat (2) dalam hal yang bagaimana sehingga dapat dikatakan presiden melanggar haluan negara. Tidak terdapat elaborasi yang dapat menjelaskan mengenai ihwal ini. Dalam ayat (3) dan ayat (4) Tap MPR No. III/MPR/1978 mengatur mengenai memorandum sebagai peringatan atas haluan negara yang telah dilanggar presiden yang dapat ditindaklanjuti agar MPR menggelar Sidang Istimewa untuk meminta pertanggungjawaban presiden.

Pada proses pemberhentian presiden dalam Tap MPR No. III/MPR/1978 tanpa adanya proses peradilan seperti $\mathrm{MK}^{73}$. Sehingga apabila seorang presiden diberhentikan berdasarkan pada Tap MPR No. III/MPR/1978 hanya didasarkan pada seberapa kuat seorang presiden mendapat dukungan parlemen atau bahkan hanya didasarkan pada subyektivitas anggota parlemen belaka.

\section{PENUTUP}

\section{Simpulan}

1. Undang-Undang Dasar 1945 adalah undang undang dasar sementara (UUD kilat) dan harus diganti dengan UUD yang baru yaitu sesudah enam bulan dibentuknya MPR . Karena sifat sementaranya UUD ini dan dibuat dengan tergesa-gesa, UUD Tahun 1945 menyisakan kekurangan di dalam pengaturan ihwal ketatanegaraan. Kekurangan yang terdapat ialah minimnya checks and

\footnotetext{
${ }^{71}$ Republik Indonesia (6), Ibid., Pasal 5 ayat (2)

${ }^{72}$ Republik Indonesia (6), Ibid., Pasal 7

${ }^{73}$ Mahkamah Konstitusi (MK) merupakan produk dari perubahan ketiga UUD Tahun 1945 yang diatur dalam Pasal 24 ayat (2) UUD Tahun 1945.
} 
balances sehingga ini membuat kekuasaan terpusat pada eksekutif (executive heavy).

2. Pemilu merupakan sarana untuk menyalurkan kedaulatan rakyat yang dijamin konstitusi. Pemilu menjunjung tinggi semangat langsung, umum, bebas, rahasia, jujur dan adil untuk memilih Presiden dan Wakil Presiden, anggota DPR, DPD, DPRD Provinsi, dan DPRD Kabupaten/Kota. Sehingga rakyat sebagai pemiliki kedaulatan tertinggi memiliki andil untuk membentuk suatu pemerintahan.

3. Setelah perubahan UUD Tahun 1945 terdapat pergeseran makna kedaulatan rakyat. Semula kedaultan tertinggi ditangan rakyat dilakukan sepenuhnya oleh MPR. Namun setelah perubahan kedaulatan dilaksanakan menurut undangundang dasar. Pergeseran ini juga terjadi pada fungsi dan kewenangan MPR. MPR tidak lagi menjadi Lembaga tertinggi negara dan MPR tidak lagi berwenang untuk memilih presiden dan wakil presiden. Perubahan sistem pemilihan ini sebagai tanda UUD Tahun 1945 menganut prinsip presidensial.

4. UUD Tahun 1945 dan Tap MPR No. III/MPR/1978 tidak mengatur secara jelas pemberhentian presiden dalam masa jabatannya dimana dugaan kesalahan presiden lebih pada subyektifitas anggota parlemen. Namun pada UUD Tahun 1945 setelah perubahan telah mengatur pemberhentian presiden dan wakil presiden dalam masa jabatannya dengan melibatkan DPR, MK dan MPR. DPR mengajukan sidang Istimewa pemberhentian presiden dan atau wakil presiden kepada MPR dengan terlebih dahulu mengajukan permintaan kepada Mahkamah Konstitusi untuk memeriksa dan mengadili bahwa presiden dan atau wakil presiden telah melakukan pelanggaran hukum berupa berupa pengkhianatan terhadap negara, korupsi, penyuapan, tindak pidana berat lainnya, atau perbuatan tercela maupun apabila terbukti tidak lagi memenuhi syarat sebagai Presiden dan/atau Wakil Presiden.

\section{Saran}

1. Rakyat sebagai pemegang kedaulatan tertinggi harus aktif dalam mensukseskan perhelatan pemilu pada setiap pemilu yang dilaksanakan dengan memilih Presiden dan Wakil Presiden, Anggota DPR, DPD, DPRD Provinsi, dan DPRD Kabupaten/Kota. Memberikan suara pada setiap pemilu merupakan langkah rakyat untuk turut serta di dalam menciptakan pemerintahan yang sesuai dengan keinginan rakyat.

2. Perubahan UUD Tahun 1945 menginginkan adanya pemurnian (purifikasi) terhadap penerapan terhadap sistem presidensial. Oleh karena itu, perlemen harus menggunakan fungsi legislasi, fungsi anggaran, dan fungsi pengawasannya sebagaimana di atur dalam UUD Tahun 1945 sehingga terciptanya mekanisme checks and balances antara presiden dan parlemen.

3. Harus ada undang-undang yang mengatur hubungan koalisi pemerintah dengan partai oposisi. Agar mekanisme checks and balances dapat diterapkan secara optimal. Pembentukan undang-undang ini perlu agar partai yang pasangan calonnya kalah dalam pilpres tidak berpindah haluan untuk masuk ke pemerintahan. Di sisi lain ihwal ini akan membuat posisi partai koalisi pemerintah dan partai oposisi memiliki derajat yang setara dalam melaksanakan fungsi-fungsi parlemen. 
Jurnal Hukum Sasana, Volume 6 Nomor 1, Juni 2020

P-ISSN 2461-0453, E-ISSN 2722-3779

DOI: https://doi.org/10.31599/sasana.v6i1.228

\section{DAFTAR PUSTAKA}

\section{Buku}

Adnan Buyung Nasution, Arus Pemikiran Konstitusionalisme : Tata Negara (Jakarta : Kasta Hasta, 2007)

Affan Gafar, Politik Indonesia: Transisi Menuju Demokrasi, (Yogyakarta : Pustaka Pelajar, 2000)

Fitra Arsil, Teori Sistem Pemerintahan : Pergeseran Konsep dan Saling Kontribusi Antar Sistem Pemerintahan di Berbagai Negara, (Depok : Rajawali Pers, 2017)

Jean Jacques Rousseau, Du Contract Social (Perjanjian Sosial), (Jakarta : Visimedia, 2009)

Jimly Asshiddiqie, Gagasan Kedaulatan Rakyat Dalam Konstitusi Dan Pelaksanaannya di Indonesia, (Jakarta : Ichtiar Baru Van Hoeve, 1999), hlm. 70

Konstitusi dan Konstitusionalisme Indonesia, (Jakarta : Konstitusi Press, 2005), hal. 59.

Pengantar Ilmu Hukum Tata Negara, (Jakarta : Sekretariat Jenderal dan Kepaniteraan Mahkamah Konstitusi, 2006), hlm. 171

Komentar Atas Undang-Undang Dasar Negara Republik Indonesia Tahun 1945, (Jakarta : Sinar Grafika, 2013), Pasal 1 ayat (2) $\mathrm{hlm} .10$

Implikasi Perubahan UUD Tahun 1945 Terhadap Pembangunan Hukum Nasional, Sambutan Pada Seminar Pengkajian Hukum Nasional (SPHN) Oleh Komisi Hukum Nasional (KHN) Republik Indonesia, Jakarta, 21 November 2005.

, Pokok-Pokok Hukum Tata Negara Indonesia Pasca Reformasi,

(PT. Buana Indah Populer, Jakarta). hlm. 292.

Moh. Kusnardi dan Harmailly Ibrahim, Pengantar Hukum Tata Negara, (Jakarta : 1981, Pusat Studi HTN UI), hlm. 328

Moh. Mahfud MD, Demokrasi dan Konstitusi Indonesia : Studi Tentang Interaksi Politik dan Kehidupan Ketatanegaraan, (Jakarta : Rineka Cipta, 2003), hlm. 147

Ni'matul Huda, Hukum Tata Negara Indonesia (edisi revisi), (Jakarta : 2014, Rajawali Pers) hlm. 118

Saldi Isra, Pergeseran Fungsi Legislasi, (Depok : Rajawali Pers, 2018) Sistem Pemerintahan Indonesia : Pergulatan Ketatanegaraan Menuju Sistem Pemerintahan Presidensial, (Depok : Rajawali Pers, 2019) 
Soewoto Mulyosudarmo, Pembaharuan Ketatanegaraan Melalui Perubahan Konstitusi, (Malang : Asosiasi Pengajar HTN dan HAN dan In-TRANS, 2004)

Soehino, Hukum Tata Negara : Perkembangan Pengaturan dan Pelaksanaan Pemilihan Umum di Indonesia, (Yogyakarta : BPFE-Yogyakarta, 2010), hal.74.

\section{Makalah :}

Jimly Asshiddiqie, Implikasi Perubahan UUD Tahun 1945 Terhadap Pembangunan Hukum Nasional, Sambutan Pada Seminar Pengkajian Hukum Nasional (SPHN) Oleh Komisi Hukum Nasional (KHN) Republik Indonesia, Jakarta, 21 November 2005

\section{Peraturan Perundang-undangan}

Undang-Undang Dasar Negara Republik Indonesia (UUD NRI) Tahun 1945 (sebelum perubahan)

Undang-Undang Dasar Negara Republik Indonesia (UUD NRI) Tahun 1945 (setelah perubahan)

Ketatapan MPR No. III/MPR/1978

Undang-Undang No. 23 Tahun 2003 tentang Pemilihan Umum Presiden dan Wakil Presiden

Undang-Undang No. 42 Tahun 2008 tentang Pemilihan Umum Presiden dan Wakil Presiden

Undang-Undang No. 7 Tahun 2017 tentang Pemilihan Umum Pasal

\section{Website :}

https://id.m.wikipedia.org/wiki/Pemilihan_umum_legislatif_Indonesia_2004

https://id.m.wikipedia.org/wiki/Pemilihan_umum_legislatif_Indonesia_2009

https://id.m.wikipedia.org/wiki/Pemilihan_umum_legislatif_Indonesia_2014

https://id.m.wikipedia.org/wiki/Pemilihan_umum_legislatif_Indonesia_2019 